\title{
Analyzing the changing education distributions of solo self-employed workers and employer entrepreneurs in Europe
}

\author{
André van Stel • Peter van der Zwan
}

Accepted: 1 March 2019/Published online: 20 August 2019

(C) The Author(s) 2019

\begin{abstract}
Using macro-level data for 32 European countries, the present paper explores developments in the education distributions among solo self-employed workers and employer entrepreneurs in the nonagricultural economy over the period 1997-2014. Our dynamic analysis reveals that over this period, the number of solo self-employed workers, but particularly the high-educated solo self-employed, has increased considerably in Europe. This trend is even more pronounced for female solo self-employment. The education distribution of the solo self-employed is thus shifting quickly towards higher levels of education. Moreover, our static analysis based on 2014 reveals that, for the higher-developed countries within Europe (Western Europe including Scandinavia), solo selfemployed and employer entrepreneurs are on average equally highly educated. We also find that the solo selfemployed in Western Europe are considerably higher educated than their counterparts in the rest of Europe. In general, our results underline the rapidly increasing importance of, particularly high-educated, solo self-
\end{abstract}

A. van Stel

Trinity Business School, Trinity College Dublin, Dublin, Ireland

A. van Stel

Kozminski University, Warsaw, Poland

P. van der Zwan $(\triangle)$

Department of Business Studies, Institute of Tax Law and

Economics, Leiden Law School, Leiden University, 2311

ES Leiden, The Netherlands

e-mail: p.w.van.der.zwan@law.leidenuniv.nl employed workers in modern, highly developed economies.

Keywords Solo self-employment · Employer entrepreneurs $\cdot$ Education distribution $\cdot$ Europe

JEL classification I21 $\cdot$ I25 $\cdot$ J24 $\cdot$ L26 $\cdot$ O52 $\cdot$ O57

\section{Introduction}

The number of solo self-employed workers - the selfemployed without employees, also known as ownaccount workers - is increasing rapidly in many European countries. For instance, in the EU-27, the nonagricultural solo self-employment rate (the number of solo self-employed outside agriculture as a percentage of the labor force) rose from $5.9 \%$ in 2000 to $7.8 \%$ in 2014 (source, Eurostat). Two explanations for this development are the increased outsourcing to freelancers by established firms, enabling firms to be more flexible and agile (Burke 2011), and the higher levels of freedom and work autonomy that can be enjoyed through (solo) self-employment (Van Gelderen and Jansen 2006).

However, different opinions exist among academics and policymakers as to whether the increase in solo selfemployment is a desirable development. Some authors suggest that solo self-employed workers are "relatively unproductive," pointing at an apparent lack of innovation among these workers (Stam 2014, p. 23). Other authors, however, claim that over the last two decades, solo self-employed workers in modern economies have 
transformed from a largely precariat shadow workforce, often serving as cheap substitutes for employees, to a more diverse workforce. This workforce incorporates high-earning and highly skilled workers who contribute to the economy by providing flexibility and innovation to both small and large businesses (Burke 2015).

The debate on the value of the solo self-employed tends to be blurred by a lack of background information on the characteristics of the solo self-employed. ${ }^{1}$ The present paper focuses on the education levels of the solo self-employed. Focusing on education levels is relevant for the debate, because formal education has been found to be an important indicator for entrepreneurial success (Kolstad and Wiig 2015; Van Praag et al. 2013) and for productivity of workers in general (Becker 1993; Jones 2001). Hence, higher-educated entrepreneurs may have a relatively higher contribution to the economy than lower-educated entrepreneurs, on average. Thus, although we recognize the two concepts are not the same, we assume that, on average, higher levels of formal education reflect higher levels of entrepreneurial ability or quality, particularly when the macro-level is concerned.

Using macro-level data for 32 European countries, the present paper's aim is to explore developments in the education distributions among solo self-employed workers and employer entrepreneurs in the nonagricultural economy over the period 1997-2014. In particular, we aim at answering the following three research questions:

1. How does the education distribution (low, medium, high) differ between solo self-employed workers and employer entrepreneurs?

2. How does the education distribution of the (solo) self-employed differ between different parts of Europe, in particular between relatively higher- and lower-developed European countries?

3. How have the differences under 1 and 2 developed over the period 1997-2014 and what has been the role of the economic crisis?

The answers to these questions will shed light on the position of solo self-employment in modern labor markets, in terms of being an attractive employment option for higher-educated labor force participants. Does the increase in solo self-employment observed in many

\footnotetext{
${ }^{1}$ Cowling and Taylor (2001) is an exception.
}

European countries represent a flow of lower-educated individuals towards self-employment, suggesting lower productivity entrepreneurship (Shane 2009; Stam 2014), or, alternatively, a flow of higher-educated individuals towards self-employment, suggesting higher productivity entrepreneurship (Burke 2015; Leighton and Brown 2013)? Such a thorough assessment of the different education distributions between solo selfemployed workers and employer entrepreneurs over time has not been provided in previous literature.

Importantly, we investigate the research questions also separately for males and females because women tend to make different labor market choices than men (Jayawarna et al. 2014; Bögenhold and Klinglmair 2015). In addition, the gender dimension seems important when comparing education levels between solo self-employed workers and employer entrepreneurs (Cowling and Taylor 2001).

The set-up of this paper is as follows. Section 2 derives hypotheses based on occupational choice theory. Sections 3-6 provide the data, methodology, results, and conclusions, respectively.

\section{Theory and hypotheses development}

2.1 Education differences between the solo self-employed and employer entrepreneurs

Occupational choice theory provides an appropriate theoretical framework to study labor market choices of individuals. In particular, we use the seminal paper by Lucas $(1978)^{2}$ as a starting point to derive a hypothesis corresponding to our first research question, which reads as "How does the education distribution (low, medium, high) differ between solo self-employed workers and employer entrepreneurs?"

Congregado et al. (2014, p. 432) describe that "In the Lucas model, individuals are homogeneous with respect to productivity in paid-employment, but they differ with respect to managerial ability in entrepreneurship (Parker 2004 , p. 55). Individuals freely choose between becoming an entrepreneur with an expected return and becoming a wage-worker earning a fixed wage. Entrepreneurs maximize profits which are an increasing function of managerial ability. In the solution of the model, the more able entrepreneurs run the largest firms." This is so

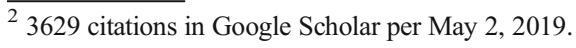


because higher entrepreneurial ability enables individuals to coordinate and manage a larger stock of resources, that is, to run a larger firm (Sorgner et al. 2017).

The characteristic of increasing returns to entrepreneurial ability in the Lucas model implies that running a firm of a certain size is only profitable (relative to running a smaller firm or working in wage-employment) for individuals above a certain entrepreneurial ability level. For individuals with lower ability levels, the coordination and management involved in running a large firm is relatively burdensome such that it is more profitable for these lower-ability individuals to run a smaller firm, more fitting with their ability level.

In the solution of the Lucas model, individuals below the "marginal ability" level ${ }^{3}$ become wage-employed because they can earn a higher income as a wageworker compared with an entrepreneur, while individuals with higher ability levels become entrepreneurs, with the size of the firm increasing in entrepreneurial ability levels. In terms of employment, employer entrepreneurs run-by definition-larger firms than solo self-employed workers, and hence, the Lucas model would predict that solo self-employed workers have lower entrepreneurial ability levels than employer entrepreneurs. ${ }^{4}$ As explained in Section 1, we use formal education as an indicator for entrepreneurial ability. The Lucas (1978) model would thus predict that, on average, solo self-employed workers are lower educated than employer entrepreneurs. ${ }^{5}$ The meta-study by Unger et al. (2011) seems to confirm this prediction empirically because they find a significant positive relation between formal education and entrepreneurial success in terms of firm size. However, their study does not distinguish between firms with and without employees; it is therefore not clear to what extent the solo self-employed are included in Unger et al.'s (2011) analysis.

Despite its high level of sophistication, Lucas' model did not take account of two developments in modern economies that are specifically related to (primarily) higher-educated solo self-employment. First, “... for

\footnotetext{
${ }^{3}$ This is the entrepreneurial ability level for which individuals are indifferent between wage-employment and self-employment because their income is the same under both conditions.

${ }^{4}$ Correspondingly, total factor productivity of solo entrepreneurs would be lower than that of employer firms (Medrano-Adán et al. 2018).

${ }^{5}$ Interestingly, the empirical application in Lucas (1978) did not include the self-employed without employees. Hence, we are the first to test empirically whether Lucas' prediction regarding firm size and entrepreneurial ability extends to the smallest possible firm size as well.
}

higher levels of economic development, different human motivations may have become important. In particular, rather than basic material and social needs which already tend to be fulfilled in developed societies, a need for autonomy and self-realization emerges (Maslow 1970). Solo self-employment is a way of working which allows for a lot of freedom and autonomy, thereby fulfilling these higher needs from the Maslow pyramid." (Van Stel and De Vries 2015, p. 74). Second, nowadays, firms are often in need of specialized labor that can be hired on a flexible basis to minimize downtime in firms. Highly specialized freelancers working on a project by project basis are the solution for established firms to fill these gaps (Burke 2011). Although both developments in solo self-employment may apply to lower-educated individuals as well, they seem to be particularly relevant for higher-educated individuals.

In sum, while the Lucas arguments predict that employer entrepreneurs are on average higher educated than the solo self-employed, the two developments mentioned above point in the opposite direction. Which arguments dominate is an empirical matter, but we believe that overall, the Lucas arguments may still prevail. Therefore, we hypothesize:

- Hypothesis 1: Employer entrepreneurs are on average higher educated than solo self-employed workers.

2.2 Education differences between higherand lower-developed countries

While our first research question zooms in on the education differences between solo self-employed workers and employer entrepreneurs, our second research question has a geographical focus. It compares the education levels of entrepreneurs in general, and solo selfemployed workers in particular, between different parts of Europe, based on levels of economic development. It reads as follows: How does the education distribution of the (solo) self-employed differ between different parts of Europe, in particular between relatively higher- and lower-developed European countries?

Again, the paper by Lucas (1978) provides a suitable framework to derive our second hypothesis. In the $\mathrm{Lu}-$ cas model, it is shown that under some plausible assumptions, a higher (physical) capital intensity, typically 
associated with a higher level of economic development, goes together with a relatively higher increase in wages compared with entrepreneurial income. In essence, it becomes relatively more attractive to become a wage-worker in higher-developed economies because there is a larger supply of safe and well-paid wage jobs. This larger supply causes the "marginal entrepreneur" to become wage-employed. ${ }^{6}$ Because in the Lucas model the marginal entrepreneur is typically the lower-ability entrepreneur running the smallest firms, the prediction is that at the low end of the self-employment spectrum, more low-educated individuals will become wageemployed rather than (solo) self-employed. This will shift the education distribution in higher-developed economies towards a lower share of lower-educated entrepreneurs, and a higher share of higher-educated entrepreneurs, which leads to the following hypothesis:

- Hypothesis 2a: Entrepreneurs (the sum of solo selfemployed workers and employer entrepreneurs) are on average higher educated in higher-developed countries than in lower-developed countries.

Moreover, regarding the two specific developments highlighted in Section 2.1-a need for autonomy by highly educated workers, and a need for specialized, flexible labor by established firms - it can be argued that these developments are particularly relevant in higher-developed economies. This is because work in higher-developed economies is more often based on knowledge intensity, where these two specific developments are most relevant. Stated differently, these developments are mainly relevant in innovation-driven economies rather than efficiency-driven economies (Porter et al. 2002). Hence, the trend of increasing numbers of highly educated solo self-employed workers may be particularly prevalent in relatively higher-developed countries. We therefore expect that especially solo selfemployed workers have higher education levels on average in higher-developed countries than in lowerdeveloped countries, which is formulated in the following hypothesis:

- Hypothesis 2b: The education gap between entrepreneurs in higher-and lower-developed countries

\footnotetext{
${ }^{6}$ The "marginal entrepreneur" is an individual whose entrepreneurial ability level equals the marginal ability. She is indifferent between wage-employment and self-employment.
}

is more pronounced for solo self-employed workers compared with that for employer entrepreneurs.

\subsection{Development of education differences} and the impact of the economic crisis

Our third research question is: How have the education distributions of solo self-employed workers and employer entrepreneurs developed over the period 1997-2014 and what has been the role of the economic crisis? Regarding the impact of the crisis on the education distribution of the solo self-employed, it is important to realize that the stock of solo self-employed workers can be influenced via the entry and the exit side. As to the entry side, it is possible that more people start businesses out of necessity, for instance, because they have lost their job during the crisis. These new necessity entrepreneurs could be lower educated or higher educated, as job losses during the crisis occurred in all parts of the economy. Indeed, prior research has not been conclusive regarding the education levels of necessity-based entrepreneurs versus opportunity-based entrepreneurs (Van der Zwan et al. 2016). In terms of the exit side, not all firms survived the economic crisis. It may be expected that entrepreneurs with lower entrepreneurial ability (more often lower educated) are more likely to quit their business than entrepreneurs with high entrepreneurial ability. Which effects dominate on either the entry or exit side is an empirical matter. We do not formulate a hypothesis regarding the impact of the crisis.

\section{Data}

We use self-employment data from the European Union Labour Force Survey (Eurostat 2018). Macro-level (aggregated) data in terms of the number of self-employed workers for 33 European countries and for 18 consecutive years (1997-2014) can be retrieved through the Eurostat website (http://ec. europa.eu/eurostat). The countries included in our sample are the 28 Member States of the European Union, together with Iceland, Macedonia, Norway, Switzerland, and Turkey. We distinguish between self-employed workers without employees (the solo self-employed) and self-employed workers with employees (the employer entrepreneurs). In addition, we 
distinguish between three levels within the education distribution: low education (less than primary, primary, and lower secondary education; ISCED $^{7}$ levels 0 2), medium education (upper secondary and postsecondary non-tertiary education; ISCED levels 3 and 4), and high education (tertiary education; ISCED levels 5-8). In our analyses, we also focus on the numbers of female and male entrepreneurs separately.

We exclude the agricultural sector from the sample such that non-agricultural (solo) self-employment is the focus of the present paper. The removal of agricultural self-employment activity is important because the nature of entrepreneurship in agriculture is structurally different from the rest of the economy (Bögenhold and Staber 1991), and because the agricultural sector has a disproportional influence on the number of (lower educated) solo self-employed workers in various countries. For example, agricultural self-employment as a fraction of total self-employment is excessive in countries such as Romania (the average across all available years in this country is about $75 \%$ ), Poland (50\%), Portugal (40\%), Turkey (40\%), and Slovenia (30\%). Hence, we focus on non-agricultural self-employment. Moreover, all analyses in the present paper relate to individuals of at least 15 years old.

Constructing our final estimation sample was not straightforward. First, macro-level data split by both educational attainment and sectoral activity (agriculture versus non-agriculture) are not available through the public Eurostat website; we requested Eurostat to provide us with the desired data. Second, detailed information by sector and educational attainment level as provided by Eurostat are known only for individuals between 15 and 74 years old, such that a raise factor was needed to arrive at estimated numbers for 15 years and older. ${ }^{8}$ Third, the data for Romania showed an erratic pattern throughout the years and hence are excluded from all analyses in this paper, resulting in a sample of 32 European countries.

\footnotetext{
${ }^{7}$ International Standard Classification of Education.

${ }^{8}$ In particular, for each entrepreneurship type (solo self-employment or employer entrepreneurship), we used a raise factor (entrepreneurs 15 years and older / entrepreneurs 15-74 years) to correct the number of entrepreneurs by education level. In most countries, this led to a marginal adjustment, but in some cases, such as solo self-employed workers in Portugal, the adjustment was more substantial, indicating a non-negligible presence of people above 74 in the labor force.
}

\section{Methodology}

\subsection{Static analysis}

In our static analysis, we compare the education distributions of the solo self-employed and employers at a given moment in time, in particular our most recent year of data (2014). Specifically, we use paired $t$ tests to compare the share of higher-educated solo selfemployed workers with the share of higher-educated employer entrepreneurs for our sample of 32 countries. These $t$ tests are performed to test hypothesis 1 . In a similar fashion, we use two-sample $t$ tests to compare the share of higher-educated entrepreneurs (of either type) between relatively higher- and lower-developed countries within Europe. These $t$ tests are performed to test hypotheses $2 \mathrm{a}$ and $2 \mathrm{~b}$.

4.2 Distinguishing between relatively higherand lower-developed countries

In hypotheses $2 \mathrm{a}$ and $2 \mathrm{~b}$, the distinction between relatively higher- and lower-developed countries is important. We make the distinction based on levels of GDP per capita. Figure 1 shows the distribution of GDP per capita for 2014 for the European countries used in this paper. The natural cut-off point lies between the UK and Italy, not only because their GDP per capita levels are just above and below the EU-28 average (25,800 euros) but also because the difference between the GDP per capita levels of these two countries $(30,500$ versus 25,300 euros) is the biggest difference between any two consecutive countries in the ranking (with the exception of the countries with the highest GDP per capita levels). Thus, we split our sample into a group of relatively highly developed European countries, running from Luxembourg to the UK in Fig. 1 (14 countries in total), and a group of relatively lower-developed European countries, running from Italy to Bulgaria in Fig. 1 (including Macedonia and Turkey; 18 countries). Figure 1 shows that the higher-developed countries include Western European countries including Scandinavia while the lower-developed countries include Mediterranean countries, countries from Central Eastern and South Eastern Europe, as well as the Baltic states. See also Appendix 1. 


\subsection{Dynamic analysis}

To answer our third research question ("How have the education distributions of solo self-employed and employer entrepreneurs developed over the period 19972014 and what has been the role of the economic crisis?"), we perform a dynamic analysis. In this dynamic analysis, we use a regression framework that explains the annual relative growth rates of the number of solo self-employed workers and employer entrepreneurs from a crisis dummy variable, a non-Western Europe dummy variable, and an intercept term. Annual relative growth is calculated as the difference in logarithms of the number of solo self-employed workers or employer entrepreneurs between two consecutive years (Törnqvist et al. 1985). ${ }^{9}$ The crisis dummy is included to investigate how the development of education-specific self-employment responded to the crisis (defined as 1 for the years from 2008 up and until 2014; 0 for all other years). The non-Western Europe dummy $(0=$ Western Europe including Scandinavia; $1=$ rest of Europe) is added to accommodate possible different growth patterns in non-Western and Western European countries. The intercept in these regressions reflects the average annual relative growth rate over the period 1998-2014 for the countries in our sample. ${ }^{10}$

Hence, self-employment growth acts as the dependent variable in a series of ordinary least squares regressions where the exact definition of the dependent variable changes across model specifications. We use the following dependent variables: (1) the growth rate of the number of solo self-employed workers; (2) idem, but restricted to low education; (3) idem, but restricted to medium education; (4) idem, but restricted to high education; (5) the growth rate of the number of employer entrepreneurs; (6) idem, but restricted to low education; (7) idem, but restricted to medium education; (8) idem, but restricted to high education; (9) the growth rate of solo self-employed workers minus the growth rate of employer entrepreneurs; (10) the growth rate of higheducated solo self-employed workers minus the growth rate of low-educated solo self-employed workers; (11) the growth rate of high-educated employer entrepreneurs minus the growth rate of low-educated employer

\footnotetext{
${ }^{9}$ Note that by calculating annual growth rates, we lose 1 year of data, i.e., 1997, the first year in our database.

${ }^{10}$ To be precise, this is the case for our reference group of relatively higher developed countries (Western European countries including Scandinavia), and for non-crisis years (value 0 of the crisis dummy).
}

entrepreneurs; and (12) the growth rate of high-educated solo self-employed workers minus the growth rate of high-educated employer entrepreneurs.

These 12 regressions will enable us to derive a detailed pattern as regards self-employment developments by education level in Europe in the last two decades. For the dynamic analysis, we use all country-year observations that are available. Standard errors robust to heteroskedasticity are used. We repeat all exercises for males and females.

\section{Results}

\subsection{Descriptive statistics on solo self-employment}

As a first exercise, we zoom in on the self-employment data-without yet paying attention to the education distribution - and inspect the development of selfemployment rates over time. For this purpose, Fig. 2 shows the percentage of non-agricultural solo selfemployed workers in the labor force ${ }^{11}$ for the years 2000 and 2014 and for five different groups of countries. ${ }^{12}$ Figure 2 reveals a general trend in that an increase in non-agricultural solo self-employment as a fraction of the total labor force can be observed. A further data inspection reveals that countries with above-average increases in their non-agricultural solo self-employment rates include Slovakia (from $4.0 \%$ in 2000 to $9.9 \%$ in 2014), the Netherlands (from 5.8 to $10.5 \%$ ), Italy (from 9.0 to $13.5 \%$ ), and the UK (from 7.8 to $11.1 \%$ ). Figure 2 also reveals structural differences in the level of non-agricultural solo self-employment, with relatively high levels in the Mediterranean countries.

As a second exercise, we show the percentage of solo self-employment in the labor force by country, for the year 2014. The results are displayed in Fig. 3.

\footnotetext{
${ }^{11}$ Information about a country's labor force is also retrieved from the Eurostat website.

${ }^{12}$ For this comparison, we focus on the year 2000 rather than 1997 (our earliest year of data) because for some years prior to 2000 and for some countries, education-specific or labor force information was not available. Moreover, for Macedonia and Switzerland Eurostat does not provide information on the labor force for any single year such that self-employment rates could not be calculated; these countries are excluded from Fig. 2 (and Fig. 3).
} 
5.2 Static analysis: education differences between the solo self-employed and employer entrepreneurs

This section presents the results of the first part of our static analysis as introduced above and focuses on the education levels of solo self-employed workers and employer entrepreneurs. For each group, we calculate the proportion of high-educated individuals. We also distinguish between Western European economies (including the Scandinavian countries) and non-Western European economies, and between males and females. ${ }^{13}$

For hypothesis 1, we test whether the percentages of highly educated individuals within the groups of solo self-employed workers and employer entrepreneurs are significantly different from each other in 2014. Column 1 in Table 1 provides paired $t$ tests for the full sample of countries and split by gender. Column 2 zooms in on the Western European sample while column 3 focuses on the non-Western European sample. ${ }^{14}$

The results in column 1 reveal that the group of employers contains a significantly larger proportion of highly educated individuals than the group of solo selfemployed workers, in line with hypothesis 1 . On average, $36 \%$ of the solo self-employed have attended higher education, while this is $40 \%$ among employer entrepreneurs. We note that this result is driven mainly by the male sample: male employers are significantly more likely to be highly educated than male solo selfemployed workers whereas for women, we do not find a significant difference between the two groups of selfemployed workers.

In terms of country groups, we observe that the higher education level of employer entrepreneurs relative to the solo self-employed holds for our non-Western European sample only (see column 3 ). Hence, in nonWestern European countries, employers are significantly higher educated than solo self-employed workers, irrespective of gender.

In sum, hypothesis 1 is supported for the overall sample, but holds mainly for males and for the nonWestern, relatively lower-developed European countries. For women in Western European countries, the

\footnotetext{
${ }^{13}$ We do not use the geographical areas underlying the group of nonWestern European countries as in Fig. 2 because the number of observations per geographical area would be too low.

${ }^{14}$ Table 1 is based on data for 32 countries in total: Macedonia and Switzerland (excluded in Section 5.1 due to missing labor force information) are also included here.
}

solo self-employed are even significantly higher educated than the employer entrepreneurs.

\subsection{Static analysis: education differences between higher- and lower-developed countries}

To proceed with our static analysis, we test whether the percentages of high-educated entrepreneurs (both solo self-employed workers and employers) differ significantly between higher- and lower-developed European economies in 2014. This is to test hypotheses $2 \mathrm{a}$ and $2 \mathrm{~b}$. Column 1 in Table 2 provides two-sample $t$ tests for selfemployment (sum of solo self-employed workers and employer entrepreneurs), while columns 2 and 3 zoom in on solo self-employment and employer entrepreneurship, respectively.

Column 1 shows that the self-employed are significantly higher educated in the Western, relatively highly developed part of Europe compared with the rest of Europe. This holds for males and females alike. Hypothesis $2 \mathrm{a}$ is thus supported. Columns 2 and 3 show that this gap between Western Europe and the rest of Europe is particularly large for solo self-employment. Whereas the "education gap" is 15 percentage points for solo selfemployment (44\% of the solo self-employed attended higher education in Western Europe versus 29\% in the rest of Europe), ${ }^{15}$ this gap is only 4 percentage points for employer entrepreneurship (42\% versus $38 \%$ ). Moreover, the gap is significant for solo self-employment but not significant for employer entrepreneurship. We observe similar patterns for males and females separately. Hypothesis $2 \mathrm{~b}$ is supported.

5.4 Dynamic analysis: development of education differences and the impact of the economic crisis

Table 3 shows the results of our dynamic analysis. We perform ordinary least squares regressions that explain the annual growth rate of the number of solo selfemployed workers and employer entrepreneurs, split by education level. The intercept in all model specifications refers to the average annual relative growth rate

\footnotetext{
${ }^{15}$ European countries with the highest shares of high-educated solo self-employed workers in 2014 are Luxembourg (69\%), Belgium $(53 \%)$, Austria $(50 \%)$, France $(46 \%)$, and Germany (45\%). At the bottom of the ranking of high educational attainment within solo selfemployment, we observe Turkey (8\%), Macedonia (12\%), Malta (15\%), Slovakia (20\%), and Portugal (22\%).
} 


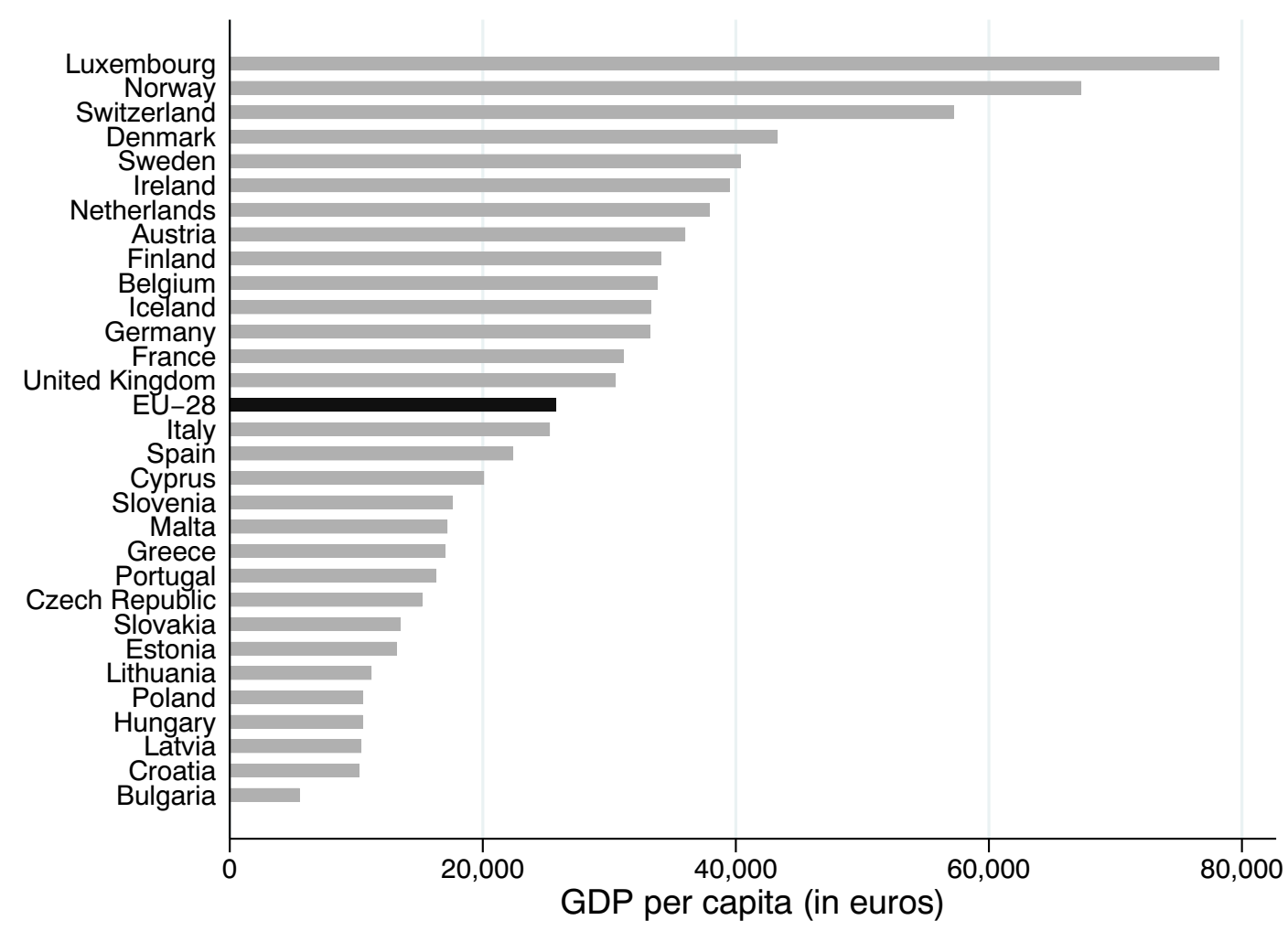

Fig. 1 GDP per capita levels in 2014. Source, Eurostat. Note: Data are not available for Macedonia and Turkey

over the period 1998-2014 in Western European countries (and in non-crisis years).

Column 1 in Table 3 focuses on solo selfemployment and reveals that there has been a significant ( $p$ value $<0.05$ ) increase in the number of solo selfemployed workers in Western European countries over the period 1998-2014. This increase is $2.6 \%$ on average (in non-crisis years, but the difference in growth between crisis and non-crisis years is not significant). Columns 2, 3, and 4 distinguish between the three levels of educational attainment in solo self-employment and show that the growth was by far the highest among the high-educated solo self-employed (5.4\% per year on average; $p<0.01$; column 4 ), followed by the medium-educated solo self-employed $(2.1 \% ; p<0.10$; column 3), and the low-educated solo self-employed ( $1.0 \%$ but with $p>0.10$; column 2 ).

Column 5 inspects the increase in employer entrepreneurs over the period 1998-2014 and finds a nonsignificant intercept (average annual growth of $1.8 \%$ but $p>0.10$ ). Focusing on the education levels in columns 6,7 , and 8 , we observe that for the low-educated (column 6) and medium-educated (column 7) employers, there has been a non-significant growth as well in Western European countries. Importantly, the number of high-educated employer entrepreneurs has risen significantly by $3.3 \%$ on average per year in Western Europe $(p<0.10)$.

While we found a significant increase in the number of solo self-employed workers and a non-significant increase for employer entrepreneurs, column 9 does not reveal a significant difference between the two growth rates. A striking result in column 10 is, however, that in Western European countries, the growth in the number of high-educated solo self-employed workers is significantly larger than the growth in the number of low-educated solo self-employed workers (difference is $4.5 \%$-points; $p<0.05$ ). Hence, for solo self-employment, the education distribution has been clearly shifting towards higher education levels. Such a significant difference is not found for the employers in column 11. Our results as discussed above revealed a significant growth in the number of high-educated solo self-employed workers and employers. The results in column 12 confirm a larger growth rate of the number of high-educated solo self-employed workers than the number of high- 


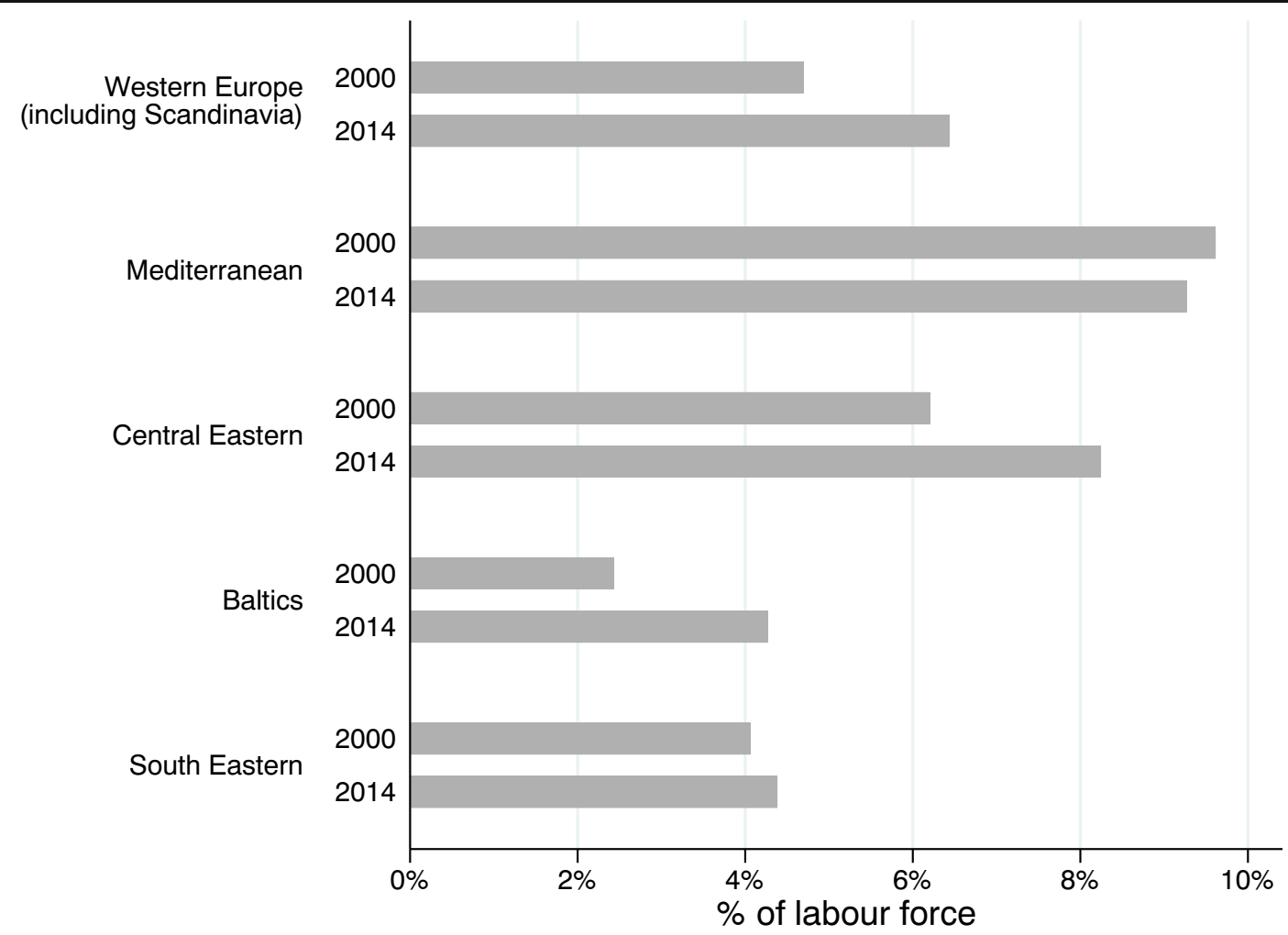

Fig. 2 Comparison of non-agricultural solo self-employment rates (as \% of the labor force) between 2000 and 2014 in five geographical regions. Notes: For each geographical area, the weighted non-agricultural solo self-employment rates in 2000 and 2014 are shown (number of solo self-employed workers outside agriculture as a fraction of the labor force). The countries included in each geographical area are given in Appendix 1. Data are not available for Macedonia and Switzerland (see footnote 12) educated employer entrepreneurs, but the growth difference is not significant between the two groups.

Another important result is that the crisis did not significantly impact the development of solo self-employed workers over the period 1998-2014 (the coefficient of the crisis dummy is non-significant in columns 1-4). In contrast, the crisis negatively impacted on the number of employer entrepreneurs (column $5 ; p<0.01$ ), and specifically the medium-educated employer entrepreneurs (column $7 ; p<0.01$ ). Clearly, the impact of the crisis is more profound for employer entrepreneurs than for solo selfemployed workers. This is an intuitive finding given the great job losses suffered in Europe during the crisis. We know that work satisfaction levels of self-employed workers are higher than those of wage-workers because of the autonomy the self-employed experience at the job (Benz and Frey 2008). It remains unanswered whether our result could also be driven by the fact that solo selfemployed workers are more likely to engage in selfemployment for such non-monetary rewards than monetary reasons, and thus are less affected by the crisis in terms of the discontinuation of their activities than employer entrepreneurs. Employers may have a higher probability of becoming financial distressed in crisis times because of their responsibility for the payment of their employees' salaries.

Finally, there does not seem to be much difference between non-Western and Western European countries in terms of the growth of the number of solo selfemployed workers and employer entrepreneurs, given the non-significance of the non-Western European dummy across the board. ${ }^{16}$

\footnotetext{
${ }^{16}$ For example, the growth of the number of high-educated solo selfemployed workers in non-Western Europe is only marginally smaller than the growth in Western Europe, and the difference between the two growth rates is non-significant. We also investigated whether the crisis affected growth rates differently in Western European and non-Western European countries, but the coefficient of the interaction term between the crisis dummy and the non-Western European dummy was never significant (results available upon request).
} 


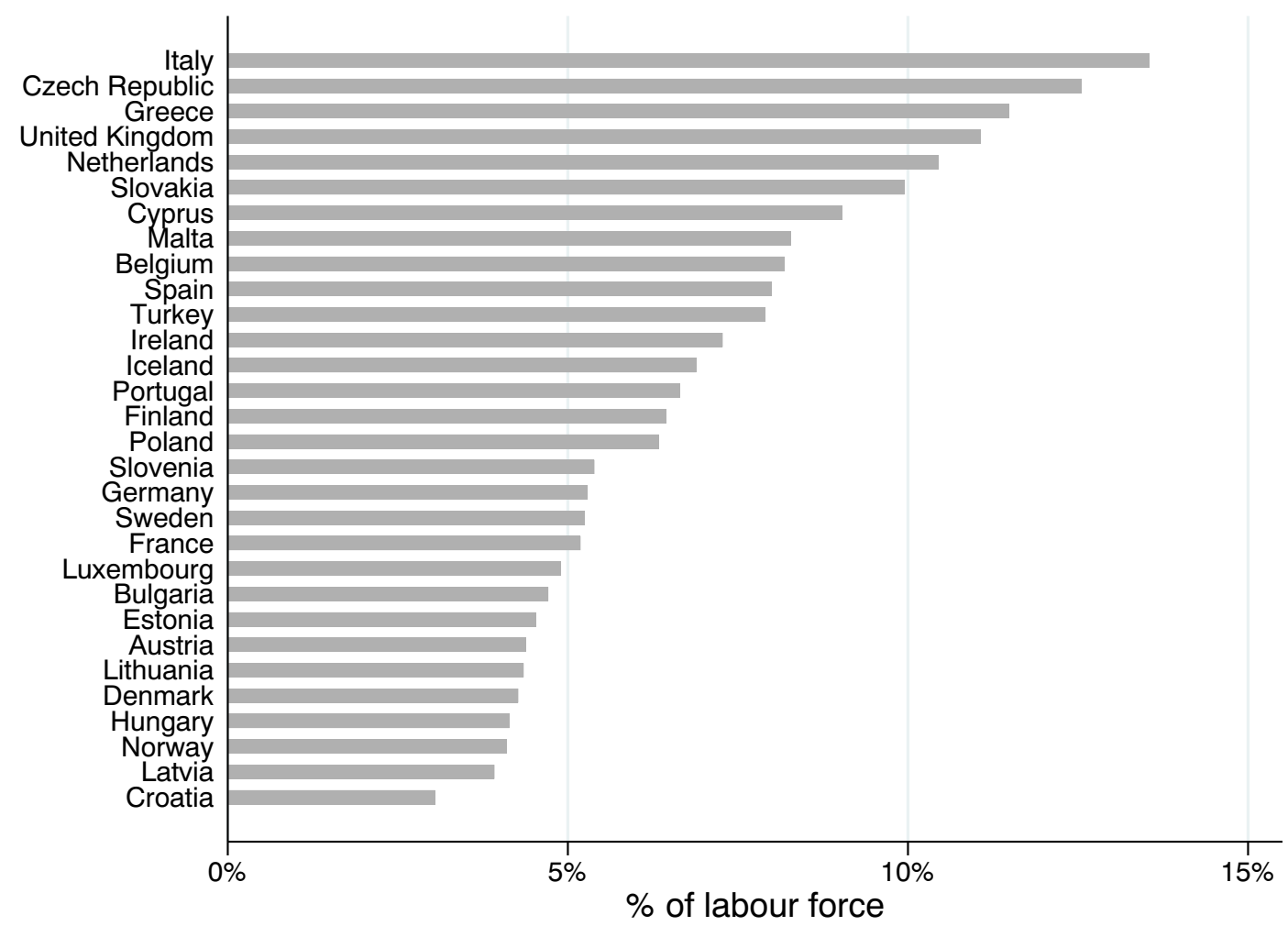

Fig. 3 Non-agricultural solo self-employment rates (as \% of the labor force) in 2014. Note: Data are not available for Macedonia and Switzerland (see footnote 12)

Table 4 repeats the exercises for the male sample and Table 5 for the female sample. As in Table 3, we also

Table 1 Comparing shares of higher-educated individuals between (non-agricultural) solo self-employment and employer entrepreneurship, 2014

\begin{tabular}{llll}
\hline & $(1)$ & $(2)$ & $(3)$ \\
& Europe & West-Europe & Rest of Europe \\
\hline Total & & & \\
$\quad$ Employers & $0.40^{* *}$ & 0.42 & $0.38^{* * *}$ \\
$\quad$ Solo self-employed & 0.36 & 0.44 & 0.29 \\
Males & & & \\
Employers & $0.38^{* * *}$ & 0.41 & $0.36^{* * *}$ \\
Solo self-employed & 0.32 & 0.41 & 0.25 \\
Females & & & \\
Employers & 0.46 & $0.46^{* *}$ & $0.46^{*}$ \\
Solo self-employed & 0.43 & 0.51 & 0.38 \\
Number of countries & 32 & 14 & 18
\end{tabular}

$* * * p$ value $<0.01, * * p$ value $<0.05, * p$ value $<0.10$. Results of paired $t$ tests are shown. West-Europe $=$ Western European including Scandinavia (14 countries); Rest of Europe $=$ Mediterranean + Central Eastern + Baltics + South Eastern (18 countries). See Appendix 1 observe a significant increase in the number of solo selfemployed workers in Tables 4 and 5, but this growth is

Table 2 Comparing shares of higher-educated (non-agricultural) entrepreneurs between West-Europe and the rest of Europe, 2014

$\begin{array}{lll}(1) & (2) & (3) \\ \text { Self- } & \text { Solo self- } & \text { Employer } \\ \text { employment } & \text { employment } & \text { entrepreneurship }\end{array}$

Total

$\begin{array}{llll}\text { West-Europe } & 0.44 * * * & 0.44 * * * & 0.42 \\ \text { Rest of Europe } & 0.32 & 0.29 & 0.38\end{array}$

Males

$\begin{array}{llll}\text { West-Europe } & 0.41 * * * & 0.41 * * * & 0.41 \\ \text { Rest of Europe } & 0.29 & 0.25 & 0.36\end{array}$

Females

$\begin{array}{llll}\text { West-Europe } & 0.49 * * & 0.50 * * * & 0.46 \\ \text { Rest of Europe } & 0.39 & 0.37 & 0.46\end{array}$

$* * * p$ value $<0.01, * * p$ value $<0.05, * p$ value $<0.10$. Results of two-sample $t$ tests are shown. West-Europe $=$ Western European including Scandinavia (14 countries); Rest of Europe $=$ Mediterranean + Central Eastern + Baltics + South Eastern (18 countries). See Appendix 1 


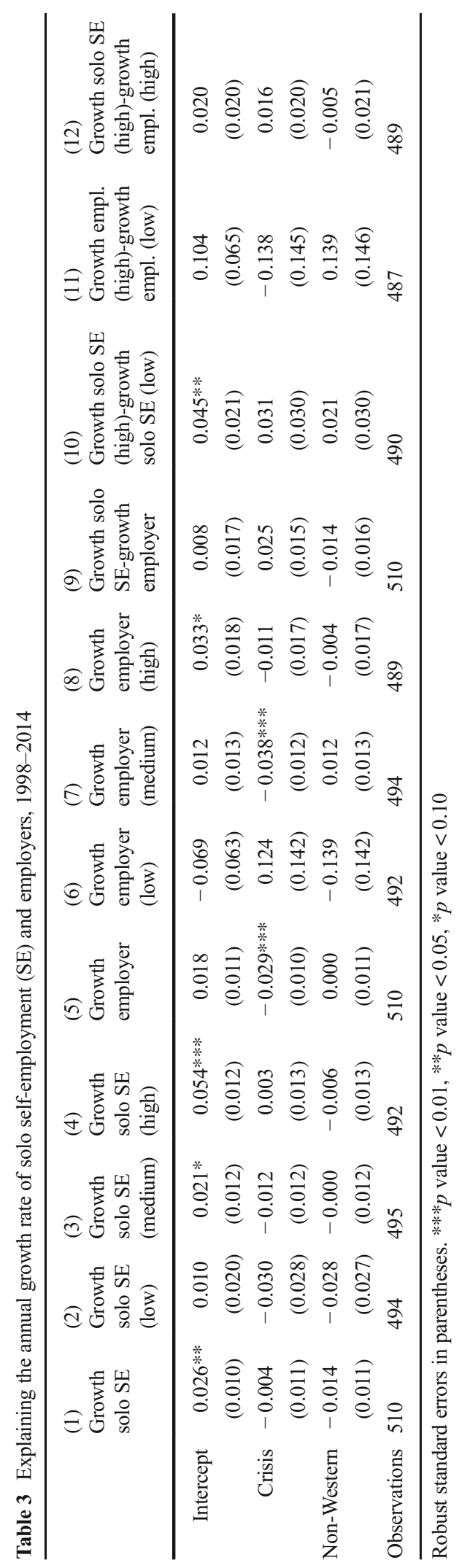




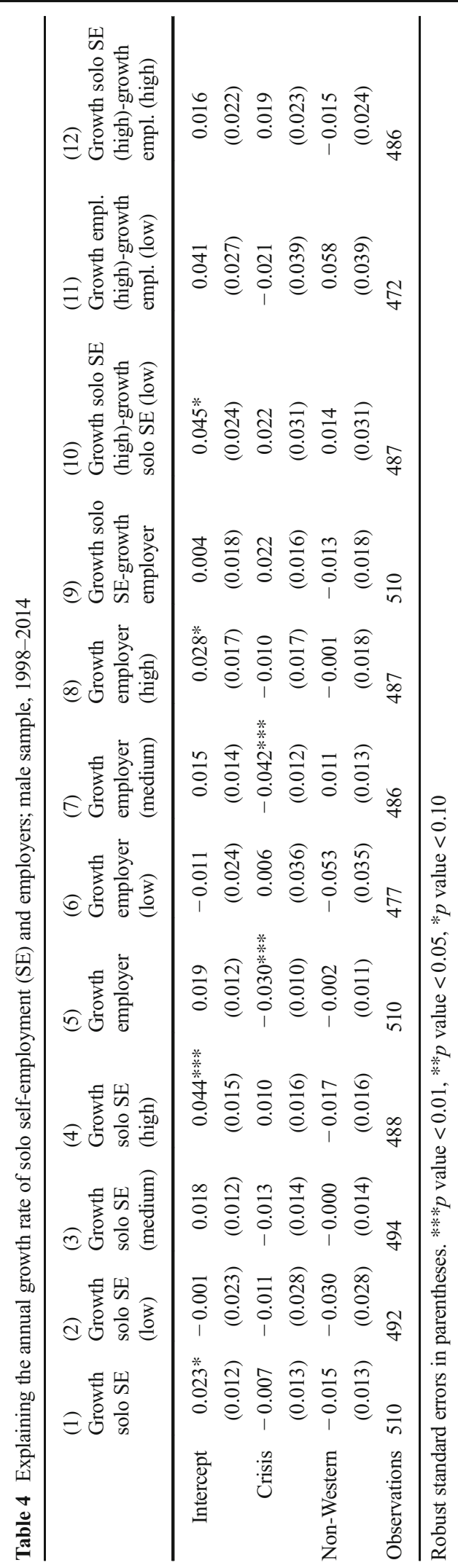




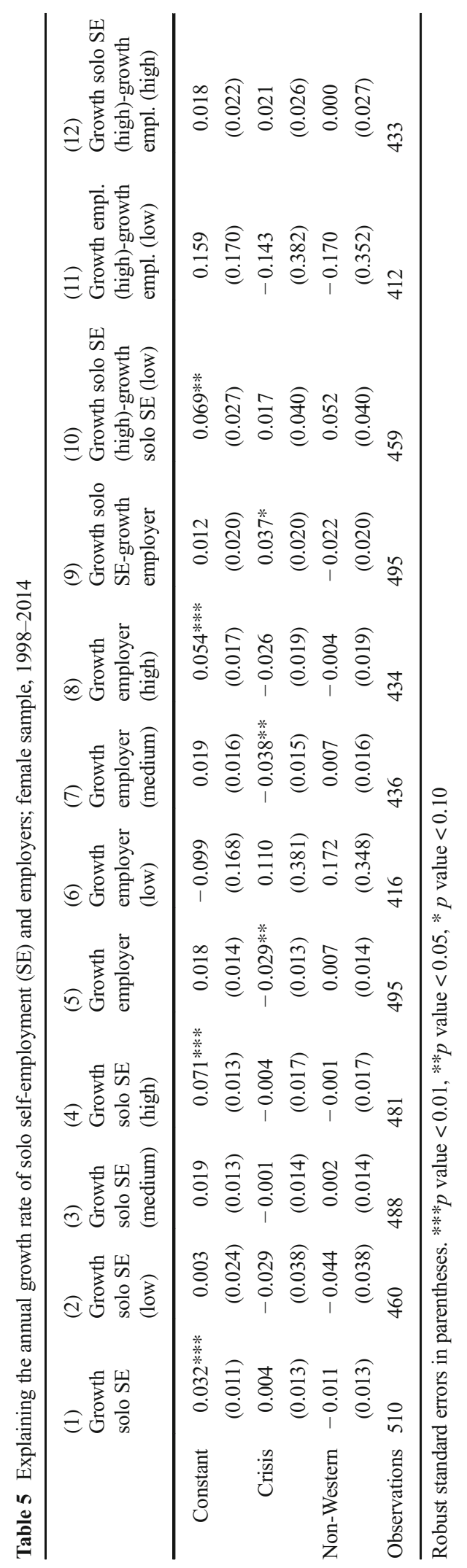


larger among women $(3.2 \% ; p<0.01)$ than among men $(2.3 \% ; p<0.10)$. For both men and women, the growth is most pronounced among the high-educated solo selfemployed workers but much more clearly so for women (7.1\% and $p<0.01$ for women and $4.4 \%$ and $p<0.01$ for men). For employers, we generally see nonsignificant growth rates for women and men (as in the full sample in Table 3) in Western Europe. As a notable exception, the growth in high-educated employers has been more prominent among women $(5.4 \% ; p<0.01)$ than among men $(2.8 \% ; p<0.10)$. Also in column 10 of Tables 4 and 5, we note that the difference in growth rate between high-educated solo self-employed workers and low-educated solo self-employed workers is more pronounced among women $(6.9 \%$-points; $p<0.05)$ than among men (4.5\%-points; $p<0.10)$. Hence, the shift towards higher education levels in the education distribution of the solo self-employed has been particularly quick for women.

\section{Conclusions}

The number of solo self-employed workers is increasing rapidly in many European countries. There is no consensus among academics and policymakers as to whether this is a desirable development, partly caused by the lack of background information on the characteristics of the solo self-employed. Using macro-level data for 32 European countries, the present paper explores developments in the education distributions among solo self-employed workers and employer entrepreneurs in the non-agricultural economy over the period 1997-2014. We find that over this period, the number of solo self-employed workers has increased considerably in Europe (with a 2.6\% average annual growth in Western Europe), but that the growth of higher-educated solo selfemployed workers (those with tertiary education) has been much stronger than the growth of lowereducated solo self-employed workers (5.4\% average annual growth versus $1.0 \%$ ). This gap is even more pronounced for female solo self-employment $(7.1 \%$ average annual growth for the high-educated female solo self-employed versus $0.3 \%$ for low-educated female solo self-employed in Western Europe). These developments show that the education distribution of the solo self-employed is shifting quickly towards higher levels of education. This trend is remarkable given that high-educated workers have very good opportunities to earn a high income in the wage job sector as well (Kher et al. 2012).

Regarding the relative education distribution of solo self-employed versus employer entrepreneurs, traditional occupational choice models (Lucas 1978) would predict that employer entrepreneurs are higher educated than solo self-employed. We find this indeed to be the case in the non-Western, relatively lower-developed countries in Europe in 2014 (our most recent year of data). However, we find that for the relatively higherdeveloped countries within Europe (Western Europe including Scandinavia) in 2014, the education distributions of both types of entrepreneurs are similar, while for females, the solo self-employed are even significantly higher educated on average than employer entrepreneurs. Furthermore, when comparing Western Europe with the rest of Europe, we find a particularly large education gap for solo self-employment: on average, the solo self-employed are much higher educated in Western Europe than in the rest of Europe. This education gap between different parts of Europe is much smaller, and non-significant, for employer entrepreneurs. We already knew that the average education level of entrepreneurs depends heavily on the country in which they are active (Cowling 2000), but in the present paper, we provide additional evidence on the origin of these differences, depending on the level of economic development, type of self-employed worker (solo selfemployed or employer entrepreneur), and gender.

While we find that solo self-employed workers and employer entrepreneurs are equally highly educated in Western Europe, we detected an interesting pattern for the female sample. That is, female solo self-employed workers are significantly higher educated than female employer entrepreneurs on average in Western Europe. Apparently, solo self-employment is an interesting path for highly educated women in Western Europe to realize their income potential. Future research should unravel whether this can be attributed to a high fraction of higheducated women among freelancers (active in "skilled non-manual occupations"; see Kitching 2015, p. 23) or among non-freelancers within the group of solo selfemployed workers. Also, future research can investigate the roles of the importance of work-life balance due to flexibility experienced in solo self-employment such as working from home (Storey et al. 2005) and the glass ceiling effect in wage-employment (Arulampalam et al. 2007) to explain this result. 
In the well-known occupational choice model of Lucas (1978), entrepreneurs with high entrepreneurial ability exploit this ability by starting and running larger firms, allowing them to benefit from economies of scale. Correspondingly, the smallest businesses are run by entrepreneurs with lower ability levels, earning an income just above the wage rate. The findings of our paper as described above show that in modern economies, the latter implication of the Lucas model no longer holds. Instead, an increasing share of the smallest, one-person businesses is run by high-educated individuals. Next to monetary motivation as emphasized by Lucas, these high-educated solo self-employed workers may be driven by the autonomy and freedom that comes with their self-employment job (Van Gelderen and Jansen 2006; Meager 2015), while the associated flexibility of working hours also facilitates an improved work-life balance (Bögenhold and Klinglmair 2015). Moreover, these high-quality professionals are expected to make an important economic contribution by introducing innovations in established firms without necessitating the latter to make a long-term commitment. This way, they allow their client firms a big degree of flexibility which is especially useful in turbulent and innovative business environments (Burke and Cowling 2015).

Our research has limitations. As our research is at the macro level, we can only identify general trends without being able to identify the exact motivations for individual workers to embark on solo self-employment. Future research at the individual level may look into this. Such research would especially be interesting among the (increasing numbers of) high-educated solo self-employed as these labor market participants have higher opportunity costs of entrepreneurship (Kher et al. 2012). Another limitation of our study is that we use formal education as a proxy for entrepreneurial ability. As mentioned in Section 1, there are good reasons to do so. Nevertheless, we recognize that in some cases, the measure may be imprecise. For instance, in some occupations, such as journalism, high-educated solo selfemployment may sometimes be a sign of necessity rather than opportunity entrepreneurship (Bögenhold and Fachinger 2013). Similarly, freelancers in some industries, such as architects and lawyers, may start on their own because of a lack of employment alternatives in the labor market. Conversely, low-educated solo selfemployment may sometimes reflect opportunitymotivated entrepreneurship, such as in the construction industry (Burke 2011). These observations point at another fruitful direction of future research which is to study the role of solo self-employment at the occupation and industry level, acknowledging deeper the vast heterogeneity in economic activities among the group of solo self-employed workers (Blanchflower 2000; CRSE 2017). Also, it may be worthwhile to focus on informal measures of human capital rather than educational attainment alone. Such informal measures, such as industry, work, management, and international experience and also informal education or training, have been shown to correlate positively with entrepreneurial success (Unger et al. 2011) and may therefore indicate entrepreneurial ability or quality. Finally, our data do not allow us to identify to what extent solo selfemployment is a permanent career path or just a transitory stage for the labor market participants involved (Block and Landgraf 2016). Future research using micro-level data may look into this issue as well.

Our paper has identified new trends and stylized facts regarding the education distributions of the solo selfemployed and employer entrepreneurs in Europe. We compared the education distributions between solo selfemployed workers and employer entrepreneurs and between higher- and lower-developed countries, and we investigated how the education distributions of both types of entrepreneurs evolved over time. In general, our results underline the rapidly increasing importance of solo self-employed workers, and particularly higheducated solo self-employed workers in modern, highly developed economies.

Funding information The paper has been written in the framework of Research Project no. 2015/19/B/HS4/00366 (Self-employment from Polish and international perspective) funded by the National Science Centre of Poland.

\section{Appendix 1. Categorization of countries}

We define the following groups of countries.

- Western Europe (including Scandinavia): Austria, Belgium, Denmark, Finland, France, Germany, Iceland, Ireland, Luxembourg, Netherlands, Norway, UK, Sweden, and Switzerland (14 countries).

- Rest of Europe/"non-Western": Mediterranean + Central Eastern + Baltics + South Eastern, with: 
- Mediterranean: Cyprus, Greece, Italy, Malta, Portugal, Spain, and Turkey (7 countries),

- Central Eastern: Czech Republic, Hungary, Poland, and Slovakia (4 countries),

- Baltics: Estonia, Latvia, and Lithuania (3 countries),

- South Eastern: Bulgaria, Croatia, Macedonia, and Slovenia (4 countries).

In our paper, "non-Western" Europe thus comprises 18 countries. As shown in Section 4.2, the categorization Western Europe versus non-Western Europe coincides with the categorization of relatively higher- versus relatively lower-developed countries (in a European context).

Open Access This article is distributed under the terms of the Creative Commons Attribution 4.0 International License (http:// creativecommons.org/licenses/by/4.0/), which permits unrestricted use, distribution, and reproduction in any medium, provided you give appropriate credit to the original author(s) and the source, provide a link to the Creative Commons license, and indicate if changes were made.

\section{References}

Arulampalam, W., Booth, A. L., \& Bryan, M. L. (2007). Is there a glass ceiling over Europe? Exploring the gender pay gap across the wage distribution. Industrial and Labor Relations Review, 60(2), 163-186. https://doi.org/10.1177 /001979390706000201.

Becker, G. S. (1993). Human Capital (3rd ed.). Chicago: University of Chicago Press.

Benz, M., \& Frey, B. S. (2008). Being independent is a great thing: subjective evaluations of self-employment and hierarchy. Economica, 75(298), 362-383. https://doi.org/10.1111 /j.1468-0335.2007.00594.x.

Blanchflower, D. G. (2000). Self-employment in OECD countries. Labour Economics, 7, 471-505. https://doi.org/10.1016 /S0927-5371(00)00011-7.

Block, J. H., \& Landgraf, A. (2016). Transition from part-time entrepreneurship to full-time entrepreneurship: the role of financial and non-financial motives. International Entrepreneurship and Management Journal, 12(1), 259282. https://doi.org/10.1007/s11365-014-0331-6.

Bögenhold, D., \& Fachinger, U. (2013). Self-employment, journalism and hybridization: the decline of a profession. Global Business \& Economics Anthology, 2, 122-131.

Bögenhold, D., \& Klinglmair, A. (2015). Female solo selfemployment - features of gendered entrepreneurship. International Review of Entrepreneurship, 13(1), 47-58.

Bögenhold, D., \& Staber, U. (1991). The decline and rise of selfemployment. Work, Employment and Society, 5(2), 223-239. https://doi.org/10.1177/0950017091005002005.
Burke, A. (2011). The entrepreneurship enabling role of freelancers: theory with evidence from the construction industry. International Review of Entrepreneurship, 9(3), 1-28.

Burke, A. (2015). Introduction: a freelancing and self-employment research agenda. In A. Burke (Ed.), The handbook of research on freelancing and self-employment (pp. iii-viii). Dublin: Senate Hall Academic Publishing.

Burke, A., \& Cowling, M. (2015). The use and value of freelancers: the perspective of managers. International Review of Entrepreneurship, 13(1), 7-20.

Congregado, E., Golpe, A., \& Van Stel, A. (2014). The role of scale economies in determining firm size in modern economies. The Annals of Regional Science, 52(2), 431-455. https://doi.org/10.1007/s00168-014-0593-5.

Cowling, M. (2000). Are entrepreneurs different across countries? Applied Economics Letters, 7(12), 785-789. https://doi. org/10.1080/135048500444804.

Cowling, M., \& Taylor, M. (2001). Entrepreneurial women and men: two different species? Small Business Economics, 16(3), 167-175. https://doi.org/10.1023/A:1011195516912.

CRSE. (2017). The true diversity of self-employment. London: Centre for Research on Self-Employment.

Eurostat (2018). EU labour force survey. Online publication. Available at: http://ec.europa.eu/eurostat/statisticsexplained/index.php?title=EU_labour_force_survey. Accessed 2 Aug 2018.

Jayawarna, D., Rouse, J., \& Macpherson, A. (2014). Life course pathways to business start-up. Entrepreneurship and Regional Development, 26(3-4), 282-312. https://doi. org/10.1080/08985626.2014.901420.

Jones, P. (2001). Are educated workers really more productive? Journal of Development Economics, 64, 57-79. https://doi. org/10.1016/S0304-3878(00)00124-3.

Kher, R., Streeter, D. H., \& Just, D. R. (2012). The "good job" trap: opportunity cost as a deterrent to immediate venture creation. International Review of Entrepreneurship, 10(4), 127-152.

Kitching, J. (2015). Tracking UK freelance workforce trends 1992-2015. International Review of Entrepreneurship, 13(1), 21-34.

Kolstad, I., \& Wiig, A. (2015). Education and entrepreneurial success. Small Business Economics, 44(4), 783-796. https://doi.org/10.1007/s11187-014-9621-1.

Leighton, P., \& Brown, D. (2013). Future working: The rise of Europe's independent professionals (iPROS). London: PCG.

Lucas, R. E. (1978). On the size distribution of business firms. Bell Journal of Economics, 9(2), 508-523. https://doi. org/10.2307/3003596.

Maslow, A. H. (1970). Motivation and personality. New York: Harper and Row.

Meager, N. (2015). Job quality and self-employment: is it (still) better to work for yourself? International Review of Entrepreneurship, 13(1), 35-46.

Medrano-Adán, L., Salas-Fumás, V., \& Sanchez-Asin, J. J. (2018). Firm size and productivity from occupational choices. Small Business Economics, 53(1), 243-267. https://doi. org/10.1007/s11187-018-0048-y.

Parker, S. C. (2004). The economics of self-employment and entrepreneurship. Cambridge: Cambridge University Press.

Porter, M. E., Sachs, J. D., \& McArthur, J. W. (2002). Competitiveness and stages of economic development. In 
M. E. Porter, J. D. Sachs, P. K. Cornelius, J. W. McArthur, \& K. Schwab (Eds.), The global competitiveness report 20012002 (pp. 16-25). New York: Oxford University Press.

Shane, S. (2009). Why encouraging more people to become entrepreneurs is bad public policy. Small Business Economics, 33(2), 141-149. https://doi.org/10.1007/s11187-009-9215-5.

Sorgner, A., Fritsch, M., \& Kritikos, A. (2017). Do entrepreneurs really earn less? Small Business Economics, 49(2), 251-272. https://doi.org/10.1007/s11187-017-9874-6.

Stam, E. (2014). The Dutch entrepreneurial ecosystem, Utrecht: birch research. Available at SSRN: http://ssrn. com/abstract=2473475. Accessed 2 Aug 2018.

Storey, J., Salaman, G., \& Platman, K. (2005). Living with enterprise in an enterprise economy: freelance and contract workers in the media. Human Relations, 58(8), 1033-1054. https://doi.org/10.1177/0018726705058502.

Törnqvist, L., Vartia, P., \& Vartia, Y. O. (1985). How should relative changes be measured? The American Statistician, 39 ( 1), 43-46. https://doi.org/10.1080 /00031305.1985.10479385.

Unger, J. M., Rauch, A., Frese, M., \& Rosenbusch, N. (2011). Human capital and entrepreneurial success: a meta-analytical review. Journal of Business Venturing, 26(3), 341-358. https://doi.org/10.1016/j.jbusvent.2009.09.004.

Van der Zwan, P., Thurik, R., Verheul, I., \& Hessels, J. (2016). Factors influencing the entrepreneurial engagement of opportunity and necessity entrepreneurs. Eurasian Business Review, 6(3), 273-295. https://doi.org/10.1007/s40821-0160065-1.

Van Gelderen, M., \& Jansen, P. (2006). Autonomy as a start-up motive. Journal of Small Bussiness and Enterprise Development, 13(1), 23-32. https://doi.org/10.1108 /14626000610645289.

Van Praag, M., Van Witteloostuijn, A., \& Van der Sluis, J. (2013). The higher returns to formal education for entrepreneurs versus employees. Small Business Economics, 40(2), 375396.

Van Stel, A., \& De Vries, N. (2015). The economic value of different types of solo self-employed: a review. International Review of Entrepreneurship, 13(2), 73-80.

Publisher's note Springer Nature remains neutral with regard to jurisdictional claims in published maps and institutional affiliations. 